ఠ ORIGINAL RESEARCH

\title{
Perceptions, barriers, and practices of medical research among students at Taibah College of Medicine, Madinah, Saudi Arabia
}

This article was published in the following Dove Press journal:

Advances in Medical Education and Practice

6 July 2015

Number of times this article has been viewed

\author{
Muatasim M Noorelahi' \\ Abdulrahman A \\ Soubhanneyaz' \\ Khaled A Kasim² \\ 'College of Medicine, ${ }^{2}$ Department \\ of Family and Community Medicine, \\ College of Medicine, Taibah University, \\ Madinah, Saudi Arabia
}

Background: Research is an extremely crucial element in the advancement and improvement of health care services provided to the public.

Aim: To assess perceptions, barriers, and practices of medical research among students at Taibah College of Medicine, Madinah, Saudi Arabia.

Methods: A cross-sectional, self-administered, validated, pretested, and structured questionnaire was completed by 233 medical students (third, fourth, and fifth study year). The questionnaire consisted of demographic data, students' attitude, practices, and barriers. The collected data were analyzed using appropriate statistical methods including predictive logistic regression models. The level of statistical significance was defined as $P \leq 0.05$.

Results: The overall response rate was $64.7 \%$ (233/360). The mean age of the studied students was $22.6 \pm 1.1$ years, of them $50.1 \%$ were males and $48.9 \%$ were females. The average attitude score was significantly higher among fourth- and fifth-year medical students compared with that of the third-year students. There has been a statistically significant difference between male and female students regarding their practice of medical research where the higher percent of students reported participation in previous medical research was among female students (79\%). The most important obstacle predictors implicated in not conducting research among all the studied students were inadequate facility for research, lack of interest by faculty or guide, and unavailability of the samples or patients.

Conclusion: The students in the study showed a moderately high positive attitude toward medical research. Addressing and solving perceived students' barriers by faculty staff and administrators are essential in order to ensure an improvement in research activities among medical students.

Keywords: attitude, knowledge, obstacles, medical research, students, undergraduate

\section{Introduction}

Research is an extremely crucial element in the advancement and improvement of health care services provided to the public. ${ }^{1}$ Exposure to health research training has been documented as an important activity in modern undergraduate medical education. ${ }^{2}$ Previous studies in various countries have attempted to gage students' attitudes, understand students' practices, and determine students' barriers and motivation toward medical research in undergraduates. ${ }^{3,4}$ It has been reported that medical students' involvement in research activity would allow them to gain research skills, thus improving patient's care. ${ }^{5}$ Hence, adequate levels of knowledge and reasoning skills and development of a positive attitude are crucial to carrying out the research. ${ }^{6}$
Correspondence: Muatasim M Noorelahi Al-Hijra Road, Scheme Prince Naif, Madinah, Saudi Arabia

Tel +966540940210

Email motasimelahi@aol.com 
Unfortunately, the number of worldwide physician scientists' has been noticed to decline recently. This has generated much interest in developing programs for early exposure to research in medical schools in order to encourage students' research activity and fill up the void of physician scientists'.$^{7-9}$ Studies have shown that the uptake of research experience during medical school and subsequent publications increase the chance of acceptance in highly competitive residency programs and improve postgraduate research productivity. ${ }^{10,11}$ However, previous reports of survey data showed that students were still facing many barriers to successfully engaging in scientific research activity. ${ }^{12,13}$

A review of literature showed that there were no data related to attitude, practice, and barriers of Taibah University (TU) medical students toward medical research. Other Saudi Arabian universities had produced data of such purpose; therefore, this study aimed to assess further characteristics of this issue at Taibah University.

\section{Objectives}

The objectives of this study were to assess attitude and practice of medical research among medical students at the College of Medicine, TU, Madinah, Saudi Arabia. Also, the study investigated barriers of conducting and publishing medical research by medical students that made them unable to participate in, complete and publish research papers.

\section{Subjects and methods}

The present study was based on a cross-sectional survey among medical students. The study was conducted at the College of Medicine, TU, from November to December 2014. The study employed a predesigned validated structured questionnaire to collect the data. The questionnaire was distributed to 360 registered students at the college, out of whom 233 students (64.7\%) have participated, filled, and returned the study questionnaire. Participation in this study survey was completely voluntary, and full confidentiality and anonymity were maintained at all times, with no identifying information being recorded in the survey results. A consent form was added at the beginning of the questionnaire explaining the purpose of the study and requesting their participation. Permission was obtained from the Dean of the College of Medicine. In addition, approval of the study by the Ethics Committee of the College Of Medicine, Taibah University, Madinah, Saudi Arabia, was obtained.

The medical program at TU is a 5-year undergraduate program with $\sim 120$ students (male and female) per year. Students attend the Medical Research block (MRES301) in the third year, and they are expected to complete a research project and to write a report at the end of the block. Accordingly, third-, fourth-, and fifth-year students of the college were considered.

\section{Data collection}

The questionnaire consisted of several parts. The first part documented the demographic data of the participants: age, sex, academic year, and marital status. Questions in the second part pertained to assessing students' attitude toward research. The third part addressed questions related to students' practices, ie, attempts to write, conduct projects, publish in journals, and oral and poster presentations. The final part questions included the barrier items that might prevent medical students to conduct or participate in the research.

\section{Study variables}

Attitudes toward conducting medical research were assessed using Likert response scale from 1 to 5 ( $1=$ totally disagree; $2=$ disagree; $3=$ neutral; $4=$ agree $5=$ totally agree). The attitude section included 14 statements representing all aspects concerning medical research. Item and scale score were reported in the range +1 to -1 . The midpoint zero corresponds to the neutral Likert scale rating of $0,+1$ corresponds to totally agree and agree, and -1 corresponds to totally disagree and disagree. Accordingly, the used 14 attitude items in the study questionnaire have a maximum score of +14 and a minimal score of -14 . A mean score for all studied attitude items was then calculated from the individual scores.

The study questionnaire also included questions about the obstacles and barriers preventing students from conducting or participating in medical research. Barrier items included in the questionnaire ( $\mathrm{n}=22$ items) were formulated according to the data available in the previous qualitative studies, $2,5,9,10,14,15$ and then categorized to include personal ( $\mathrm{n}=6$ items) and institutional aspects ( $\mathrm{n}=16$ items). Each studied barrier item was scored as follows: $1=$ totally disagree; $2=$ disagree; $3=$ neutral; $4=$ agree; $5=$ totally agree. To examine the most important barriers (predictors) preventing students from contributing in research, each of the studied barrier item was scored as follows: totally agree and agree $=1$, whereas totally disagree, disagree, and neutral $=0$.

\section{Statistical analysis}

The collected data were entered and analyzed using statistical package for social science, version 16 (SPSS Inc., Chicago, IL, USA). Data were presented using frequencies, mean, and standard deviation as appropriate. The students' attitude and practice were assessed, analyzed, and compared by the 
students' sex (male vs female) and the study year using unpaired $t$-test for continuous variables, chi-squared test for categorical variables, and one way analysis of variance for multiple comparisons. For all purposes, the criteria of significance were considered at a $P$-value of $\leq 0.05$. Furthermore, the barrier items preventing students from conducting and participating in research were assessed according to its used five scores among all studied subjects as well as by students' sex using predictive logistic regression models based on the stepwise regression with a $P$-value of 0.10 as an entry criterion and a $P$-value of 0.15 as an exclusion criterion. The studied items were entered in the regression model as follows: totally agree and agree $=1$, whereas totally disagree, disagree, and neutral $=0$.

\section{Results}

The response rate in this study was $66.1 \%$ among male students (119 out of 180) and 63.3\% among female students (114 out of 180), and the overall response rate was $64.7 \%$ (233 out of 360 ).

Table 1 presents the identification data of the studied subjects. The mean age was $22.6 \pm 1.1$ years, of whom $51.1 \%$ were males and $48.9 \%$ were females. About $30 \%$ of the study subjects were from the third year, $34 \%$ and $36 \%$ were from the fourth and fifth years, respectively. The percent of married students in the studied sample was $6.9 \%$.

Table 2 shows the distribution of the studied subjects according to the attitude scale. Students reported a high percent of agree and totally agree toward almost all the studied attitude items. More than $70 \%$ of the studied subjects reported that they agree and totally agree for the first, second, and tenth attitude items. For other studied attitude items, however, the percentage of subjects agreeing and totally agreeing varied from $15 \%$ to $<70 \%$ among the studied students.

Table I Characteristics of studied students

\begin{tabular}{ll}
\hline Characteristics & $\mathbf{N}=\mathbf{2 3 3}$ \\
\hline Age in years, mean \pm SD (range) & $22.6 \pm \mathrm{I} . \mathrm{I}(20-25)$ \\
Sex & \\
$\quad$ Male & $\mathrm{I} 19(5 \mathrm{I} . \mathrm{I})$ \\
$\quad$ Female & $\mathrm{I} 14(48.9)$ \\
Study year & \\
$\quad$ Third & $68(29.2)$ \\
$\quad$ Fourth & $79(33.9)$ \\
$\quad$ Fifth & $86(36.9)$ \\
Marital status & \\
$\quad$ Single & $217(93.1)$ \\
$\quad$ Married & $16(6.9)$ \\
\hline
\end{tabular}

Notes: Data are presented as mean \pm SD or as $\mathrm{n}(\%)$. Abbreviation: SD, standard deviation.
Table 2 Frequency distribution of the studied students in research attitude scale

\begin{tabular}{|c|c|c|c|c|c|}
\hline Attitude & I & 2 & 3 & 4 & 5 \\
\hline $\begin{array}{l}\text { I. Role of research in the medical } \\
\text { field is important. }\end{array}$ & 4.2 & 3.9 & 6.0 & I5.5 & 70.4 \\
\hline $\begin{array}{l}\text { 2. Conducting a research during } \\
\text { medical school is important. }\end{array}$ & 5.2 & 8.2 & 16.3 & 28.3 & 42.0 \\
\hline $\begin{array}{l}\text { 3. Research participating should be } \\
\text { made compulsory to all medical } \\
\text { students. }\end{array}$ & 10.7 & 12.9 & 26.2 & 26.2 & 23.0 \\
\hline $\begin{array}{l}\text { 4. Teaching research methodology } \\
\text { should be part of the curriculum. }\end{array}$ & 6.9 & 8.6 & 18.0 & 26.6 & 39.9 \\
\hline $\begin{array}{l}\text { 5. Research conduction during } \\
\text { medical school has positive } \\
\text { impact on medical students. }\end{array}$ & 6.4 & 8.2 & 17.6 & 29.6 & 38.2 \\
\hline $\begin{array}{l}\text { 6. Your research record should } \\
\text { be an important criterion for } \\
\text { acceptance in residency. }\end{array}$ & 15.0 & 12.9 & 32.2 & 22.3 & 17.6 \\
\hline $\begin{array}{l}\text { 7. Research conduction reinforce } \\
\text { teamwork spirit. }\end{array}$ & 3.0 & 9.9 & 23.6 & 35.2 & 28.3 \\
\hline $\begin{array}{l}\text { 8. Research will be a part of long- } \\
\text { term career goals. }\end{array}$ & 3.4 & 6.9 & 21.0 & 33.9 & 34.8 \\
\hline $\begin{array}{l}\text { 9. Anticipate a good understanding } \\
\text { of research methodology. }\end{array}$ & 3.4 & 9.8 & 39.5 & 30.1 & 17.2 \\
\hline $\begin{array}{l}\text { 10. Patient outcome improves with } \\
\text { continued medical research. }\end{array}$ & 3.5 & 2.1 & 18.0 & 33.5 & 42.9 \\
\hline $\begin{array}{l}\text { II. Medical student should not be } \\
\text { involved in medical research. }\end{array}$ & 41.2 & 18.8 & 15.5 & 11.6 & 12.9 \\
\hline $\begin{array}{l}\text { I2. Undertaken research } \\
\text { increases burden in already } \\
\text { over-curriculum (heavy load - } \\
\text { educational or clinical) medical } \\
\text { student. }\end{array}$ & 7.7 & 11.6 & 37.8 & 28.3 & 14.6 \\
\hline $\begin{array}{l}\text { 13. Medical student can plan and } \\
\text { conduct research project } \\
\text { without supervision. }\end{array}$ & 31.8 & 31.3 & 20.6 & 11.6 & 4.7 \\
\hline $\begin{array}{l}\text { 14. You encouraged by your seniors } \\
\text { to get involved in any research } \\
\text { activity. }\end{array}$ & 18.0 & 21.9 & 21.9 & 25.3 & 12.9 \\
\hline
\end{tabular}

Notes: Data are presented as \%. Attitudes toward conducting medical research were assessed using Likert response scale from I to 5 ( $I=$ totally disagree; $2=$ disagree; $3=$ neutral; $4=$ agree; $5=$ totally agree).

Table 3 presents the percent distribution of the studied attitude items among the studied subjects by their sex. With the exception of the attitude item named "Medical students should not be involved in medical research", there have been statistically significant differences between male and female students regarding their reporting about all studied attitude items. For that item, the percent of female students reported that they totally disagree and disagree was higher $(70.0 \%)$ compared to that reported among male students $(50.0 \%)$.

Table 4 displays the average attitude score among the studied subjects by their sex and study year. The average attitude score was significantly higher among fourth- and fifth-year medical students compared with that of the 
Table 3 Frequency distribution of male and female students in research attitude scale

\begin{tabular}{|c|c|c|c|c|c|c|c|}
\hline Attitude items & Student sex & I & 2 & 3 & 4 & 5 & $P$-value \\
\hline \multirow{2}{*}{$\begin{array}{l}\text { I. Role of research in the medical field is } \\
\text { important. }\end{array}$} & Female & 4.3 & 4.4 & 5.3 & 19.3 & 66.4 & 0.50 \\
\hline & Male & 4.2 & 3.4 & 6.7 & 11.4 & 74.6 & \\
\hline \multirow{2}{*}{$\begin{array}{l}\text { 2. Conducting a research during medical school } \\
\text { is important. }\end{array}$} & Female & 4.4 & 5.3 & 16.7 & 30.7 & 43.0 & 0.54 \\
\hline & Male & 5.9 & 10.9 & 10.9 & 26.0 & 41.2 & \\
\hline \multirow{2}{*}{$\begin{array}{l}\text { 3. Research participating should be made } \\
\text { compulsory to all medical students. }\end{array}$} & Female & 11.4 & 11.4 & 23.7 & 26.3 & 27.2 & 0.75 \\
\hline & Male & 10.1 & 14.3 & 28.6 & 26.0 & 21.0 & \\
\hline \multirow{2}{*}{$\begin{array}{l}\text { 4. Teaching research methodology should be } \\
\text { part of the curriculum. }\end{array}$} & Female & 6.1 & 9.7 & 19.3 & 22.8 & 42.11 & 0.70 \\
\hline & Male & 7.5 & 7.6 & 16.8 & 30.2 & 37.8 & \\
\hline \multirow{2}{*}{$\begin{array}{l}\text { 5. Research conduction during medical school } \\
\text { has positive impact on medical students. }\end{array}$} & Female & 7.0 & 5.3 & 15.8 & 32.4 & 39.5 & 0.47 \\
\hline & Male & 5.9 & 11.0 & 19.3 & 26.8 & 36.9 & \\
\hline \multirow{2}{*}{$\begin{array}{l}\text { 6. Your research record should be an important } \\
\text { criterion for acceptance in residency. }\end{array}$} & Female & 11.4 & 12.2 & 32.5 & 22.8 & 21.1 & 0.47 \\
\hline & Male & 18.4 & 13.5 & 32.0 & 21.8 & 14.3 & \\
\hline \multirow{2}{*}{$\begin{array}{l}\text { 7. Research conduction reinforces teamwork } \\
\text { spirit. }\end{array}$} & Female & 4.4 & 13.1 & 21.0 & 30.7 & 30.7 & 0.18 \\
\hline & Male & 1.7 & 6.7 & 26.0 & 39.5 & 26.1 & \\
\hline \multirow{2}{*}{$\begin{array}{l}\text { 8. Research will be a part of long-term career } \\
\text { goals. }\end{array}$} & Female & 5.3 & 5.2 & 21.0 & 32.5 & 36.0 & 0.51 \\
\hline & Male & 1.7 & 8.4 & 21.0 & 35.3 & 33.6 & \\
\hline \multirow{2}{*}{$\begin{array}{l}\text { 9. Anticipate a good understanding of research } \\
\text { methodology. }\end{array}$} & Female & 4.4 & 11.4 & 40.3 & 26.3 & 17.5 & 0.69 \\
\hline & Male & 2.5 & 8.4 & 38.7 & 33.6 & 16.8 & \\
\hline \multirow{2}{*}{$\begin{array}{l}\text { 10. Patient outcome improves with continued } \\
\text { medical research. }\end{array}$} & Female & 3.5 & 1.7 & 16.7 & 37.7 & 40.4 & 0.75 \\
\hline & Male & 3.4 & 2.5 & 19.3 & 29.4 & 45.4 & \\
\hline \multirow{2}{*}{$\begin{array}{l}\text { 11. Medical student should not be involved in } \\
\text { medical research. }\end{array}$} & Female & 50.0 & 20.0 & 13.2 & 7.8 & 9.0 & $0.03 *$ \\
\hline & Male & 32.8 & 17.2 & 17.6 & 15.6 & 16.8 & \\
\hline \multirow{2}{*}{$\begin{array}{l}\text { 12. Undertaken research increases burden } \\
\text { in already over-curriculum (heavy load - } \\
\text { educational or clinical) medical student. }\end{array}$} & Female & 7.0 & 13.2 & 37.7 & 28.1 & 14.0 & 0.95 \\
\hline & Male & 8.4 & 10.1 & 37.8 & 28.6 & 15.1 & \\
\hline \multirow{2}{*}{$\begin{array}{l}\text { 13. Medical student can plan and conduct } \\
\text { research project without supervision. }\end{array}$} & Female & 36.8 & 32.5 & 16.7 & 9.6 & 4.4 & 0.35 \\
\hline & Male & 26.9 & 30.3 & 24.3 & 13.5 & 5.0 & \\
\hline \multirow{2}{*}{$\begin{array}{l}\text { 14. You encouraged by your seniors to get } \\
\text { involved in any research activity. }\end{array}$} & Female & 17.5 & 27.2 & 21.1 & 24.5 & 9.7 & 0.30 \\
\hline & Male & 18.5 & 16.8 & 22.7 & 26.0 & 16.0 & \\
\hline
\end{tabular}

Notes: *Statistically significant. Data are presented as \% (with the exception of the $P$-values). Attitudes toward conducting medical research were assessed using Likert response scale from $I$ to 5 ( $I=$ totally disagree; $2=$ disagree; $3=$ neutral; $4=$ agree; $5=$ totally agree).

third-year students. Although the average attitude score was higher among male students (4.5 \pm 5.3$)$ compared with that among female students $(4.1 \pm 5.3)$, there was no statistically significant difference $(P=0.45)$.

Table 5 presents the distribution of the studied subjects according to their practice of medical research. There has been a statistically significant difference between male and female students regarding their practice of medical research,

Table 4 Average attitude score among the studied students by their characteristics

\begin{tabular}{lll}
\hline Student characteristics & Mean \pm SD & P-value \\
\hline Sex & & \\
$\quad$ Male & $4.5 \pm 5.3$ & 0.45 \\
$\quad$ Female & $4.1 \pm 5.1$ & \\
Study year & & \\
$\quad$ Third & $3.0 \pm 5.3$ & $0.04^{*}$ \\
$\quad$ Fourth & $4.9 \pm 4.9$ & \\
$\quad$ Fifth & $4.9 \pm 5.2$ & \\
\hline
\end{tabular}

Note: *Statistically significant.

Abbreviation: SD, standard deviation. with a higher percent of female students reporting contribution in previous medical researches $(79 \%)$. There have also been statistically significant differences in students' practice of medical research by their study year. The higher proportion of students participating in research was among fifth-year students $(86.0 \%)$, followed by fourth-year students $(64.5 \%)$.

Table 6 presents the barrier predictors preventing students from contributing to or conducting medical research.

Table 5 Distribution of the studied students by their research practice

\begin{tabular}{llll}
\hline Characteristics & \multicolumn{2}{l}{ Research practice, $\mathbf{n}(\%)$} & P-value \\
\cline { 2 - 3 } & Yes (n=164) & No (n=69) & \\
\hline Sex & $74(62.0)$ & $45(38.0)$ & $0.0 I^{*}$ \\
$\quad$ Male & $90(79.0)$ & $24(21.0)$ & \\
$\quad \begin{array}{l}\text { Female } \\
\text { Study year }\end{array}$ & & \\
$\quad$ Third & $39(57.0)$ & $29(43.0)$ & $0.0002^{*}$ \\
$\quad$ Fourth & $51(64.5)$ & $28(35.5)$ & \\
$\quad$ Fifth & $74(86.0)$ & $12(14.0)$ & \\
\hline
\end{tabular}

Note: *Statistically significant. 
Table 6 Barriers of not contributing in medical research: results of predictive logistic regression analysis

\begin{tabular}{|c|c|c|c|c|}
\hline & $\beta$ coefficient* & $\begin{array}{l}\text { Score test } \\
\text { value }\end{array}$ & SE** & $P$-value \\
\hline \multicolumn{5}{|l|}{ All students } \\
\hline Inadequate facility for research & 0.67 & 5.40 & 0.29 & $0.02 * * *$ \\
\hline Difficulty in obtaining a research supervisor & 0.48 & 3.85 & 0.29 & 0.10 \\
\hline Unavailability of the samples (or patients) & 0.69 & 4.90 & 0.31 & $0.02 * * *$ \\
\hline \multicolumn{5}{|l|}{ Male students } \\
\hline Inadequate facility for research & 1.20 & 9.5 & 0.40 & $0.002^{* * *}$ \\
\hline Inadequate support by mentors/assistant & 0.75 & 3.83 & 0.38 & $0.004 * * *$ \\
\hline \multicolumn{5}{|l|}{ Female students } \\
\hline Lack of rewarding and/or motivation & 1.22 & 5.10 & 0.54 & $0.02 * * *$ \\
\hline Difficulty obtaining approval for the study & 1.83 & 9.40 & 0.60 & $0.002^{* * *}$ \\
\hline Unavailability of the samples (or patients) & 1.50 & 6.60 & 0.58 & $0.01 * *$ \\
\hline
\end{tabular}

Notes: *Beta-coefficient of the predictive regression model; **SE; ***statistically significant.

Abbreviation: SE, standard error.

According to predictive regression analysis, the most important obstacle predictors implicated in not conducting research among all the studied subjects were inadequate facility for research, lack of interest by faculty or guide, and unavailability of the samples or patients. These obstacles showed significantly increased probability of not conducting a research according to the obtained statistical parameters. The obstacle items named inadequate facility for research and inadequate support by mentors or assistant were the most important obstacles among male students, and the items named lack of rewarding and/or motivation, difficulty obtaining approval for the study, and unavailability of the samples or patients were the most important barrier predictors among female students.

\section{Discussions}

Research is an extremely crucial element in advancement and improvement of health care services provided to the public. ${ }^{1}$ An adequate level of knowledge, positive attitude, and reasoning skills play an important role in carrying out research. ${ }^{6}$ This study aimed to assess perceptions, barriers, and practice of Taibah medical students toward medical research. Encouragingly, out of 233 medical students, positive attitude toward medical research have been shown in about $70 \%$ in our study. In the present study, attitude score of medical students toward medical research significantly improved with more senior students in the advanced academic year. In the present study, although attitude score among males was better than among females, no statistically significant difference was found, with the exception of the studied eleventh item. Vujaklija et $\mathrm{a}^{16}$ have also reported similar findings, where they documented an increase in attitude score as junior students moved to senior students. ${ }^{16}$ Also, a study by Nel et al ${ }^{7}$ showed that the importance of research participation was felt by $74 \%$ of studied subjects, which is a similar meaning of item number $11 .^{7}$

The present study has also revealed a direct relationship between students' practice of medical research and their academic year. In addition, the study has shown a significant relationship between students' sex and practice of medical research, where female students were more practicable to medical research in TU.

In our study, the studied male and female students' reported significant barriers impeding research during undergraduate education, such as inadequate facility to research and unavailability of the samples (or patients). A possible explanation of this finding could be due to under-construction of a new forward-looking university. Our study also shows that inadequate support by mentors or assistant to be the second major obstacle that prevents male medical students from conducting research. This finding has appeared to be consistent with findings of other studies. ${ }^{1,14-17}$ On the other hand, Al-Shalawy ${ }^{18}$ reported in his research that the major barriers to females conducting medical research were the lack of rewards and/or motivation and difficulty in obtaining approval for the study. The reason for the obstacle to research among females was explained by Abu-Zaid and Altinawi, ${ }^{19}$ who noticed a strict separation of males and females in the work environment, and both were supervised by a male manager.

A recent research by Mitwalli et al, ${ }^{2}$ included 191 physician and residents in Riyadh hospitals, reported that a majority of studied physicians and residents (97.9\%) agreed that research is essential and improves health care and $86.9 \%$ agreed that it helps in building a future academic career. In that study, the most important barriers in doing research were lack of research training $(93.2 \%)$, lack of time (89.5\%), workrelated stress $(83.2 \%)$, and lack of supervisors $(73.3 \%)$. The 
practice of studied residents and physicians showed only 58 $(30.4 \%)$ to have had any involvement in research.

The inadequate support by mentors or assistants observed as a major barrier to conducting research among male students in this study was also reported by Shahab et $\mathrm{al}^{20}$ who concluded that proper guidance should be given to making conducting research easier.

The present study appeared to have a number of strengths. The study questionnaire was comprehensive and addressed almost all medical research perception items as well as wide range of personal and institutional barrier factors. Also, the study questionnaire has been validated by an epidemiologist and medical research experts. To the best of our knowledge, this study is the first to study the perceptions, barriers, and practice of medical research among medical students in Saudi Arabia. Moreover, the use of predictive regression models helps to examine and quantify the most important barriers implicated in not conducting research among medical students. Dissemination of these findings at the college level is as important as encouraging students to think about their perceptions and how they might improve and also trying to discuss and solving the most important obstacles that prevent students from participating in the research activities by the college administrators.

This study also has a number of limitations. Self-selection bias may have been a limitation factor in this study because those students who chose to participate may be more familiar with medical research. However, because of the small refuse rate encountered in this study and the inclusion of only senior students (third, fourth, and fifth grades) who attended and completed a medical research course, this factor appeared to have little or no role in the study findings. Additionally, this study included only students from one college and a modest sample size. Future research will need to include multicollege design to assess the extent to which the results of this study are generalizable.

\section{Conclusion}

The perception of the students toward medical research was favorable in both male and female students. However, the practice was higher among female students. A numbers of barriers were found to prevent students from conducting a research. Addressing and solving these barriers by the faculty staff and administrators are required in order to ensure an improvement in research activities among medical students in the faculty.

\section{Acknowledgments}

The authors would like to acknowledge with great thanks all of the participants who took part in this study. Also, the authors would like to acknowledge the valuable task performed by their colleagues in data collection. There was no fund taken from any institution to carry out this study. This paper and the abstract of this paper were presented at the "Preparatory Forum of Sixth Scientific Conference for Students of Higher Education in Kingdom of Saudi Arabia", Taibah University, Medina, Saudi Arabia, as an oral presentation with interim findings.

\section{Author contributions}

Muatasim M Noorelahi conceived the idea. All authors contributed toward data analysis, drafting and critically revising the paper, and agree to be accountable for all aspects of the work.

\section{Disclosure}

The authors report no conflicts of interest in this work.

\section{References}

1. Khamis N, Ibrahim R, Fetyani DM. Assessment of the research-oriented knowledge, attitude and practice of medical students and interns of the King Abdulaziz University, Jeddah and the adoption of a researchintervention educational program. RMJ. 2013;38(4):432-439.

2. Mitwalli H, Al Ghamdi K, Moussa N. Perceptions, attitudes, and practices towards research among resident physicians in training in Saudi Arabia. EMHJ. 2014;20:99-104.

3. Burgoyne LN, O'Flynn S, Boylan GB. Undergraduate medical research: the student perspective. Med Educ Online. 2010;15:5212.

4. Amin TT, Kaliyadan F, Al Qattan EA, Al Majed MH, Al Khanjaf HS, Mirza M. Knowledge, attitudes and barriers related to participation of medical students in research in three Arab Universities. Educ Med J. 2012;4(1):e43-e56.

5. Al-Halabi B, Marwan Y, Hasan M, Alkhadhari S. Extracurricular research activities among senior medical students in Kuwait: experiences, attitudes, and barriers. Adv Med Educ Pract. 2014;5:95-101.

6. Pawar DB, Gawde SR, Marathe PA. Awareness about medical research among resident doctors in a tertiary care hospital: a cross-sectional survey. Perspect Clin Res. 2012;3(2):57-61.

7. Nel D, Burman RJ, Hoffman R, Randera-Rees S. The attitudes of medical students to research. SAMJ South African Med J. 2014;104(1):32-36.

8. Khan H, Khawaja MR, Waheed A, Rauf MA, Fatmi Z. Knowledge and attitudes about health research amongst a group of Pakistani medical students. BMC Med Educ. 2006;6(1):54.

9. Siemens DR, Punnen S, Wong J, Kanji N. A survey on the attitudes towards research in medical school. BMC Med Educ. 2010;10(1):4.

10. Alghamdi KM, Moussa NA, Alessa DS, Alothimeen N, Al-Saud AS. Perceptions, attitudes and practices toward research among senior medical students. Saudi Pharm J. 2014;22(2):113-117.

11. Murdoch-Eaton D, Drewery S, Elton S, et al. What do medical students understand by research and research skills? Identifying research opportunities within undergraduate projects. Med Teach. 2010;32(3): e152-e160.

12. De Oliveira NA, Luz MR, Saraiva RM, Alves LA. Student views of research training programmes in medical schools. Med Educ. 2011;45(7):748-755.

13. Takahashi O, Ohde S, Jacobs JL, Tokuda Y, Omata F, Fukui T. Residents' experience of scholarly activities is associated with higher satisfaction with residency training. J Gen Intern Med. 2009;24(6):716-720.

14. Giri PA, Bangal VB, Phalke DB. Knowledge, attitude and practices towards medical research amongst the postgraduate students of Pravara Institute of Medical Sciences University of Central India. J Fam Med Prim care. 2014;3(1):22-24. 
15. Alsayed N, Eldeek B, Tayeb S, Ayuob N, Al-Harbi A. Research practices and publication obstacles among interns at King Abdulaziz University Hospital, Jeddah, Saudi Arabia, 2011-2012. J Egypt Public Health Assoc. 2012;87(3-4):64-70.

16. Vujaklija A, Hren D, Sambunjak D, et al. Can teaching research methodology influence students' attitude toward science? Cohort study and nonrandomized trial in a single medical school. J Investig Med. 2010;58(2):282-286.

17. Griffin MF, Hindocha S. Publication practices of medical students at British medical schools: experience, attitudes and barriers to publish. Med Teach. 2011;33(1):e1-e8.
18. Al-Shalawy F. Knowledge, attitudes and perceived barriers towards scientific research among undergraduate health sciences students in the Central Province of Saudi Arabia. High Educ. 2014;4:5.

19. Abu-Zaid A, Altinawi B. Perceived barriers to physician-scientist careers among female undergraduate medical students at the College of Medicine - Alfaisal University: a Saudi Arabian perspective. Med Teach. 2014;36(Suppl 1):S3-S7.

20. Shahab F, Ali MA, Hussain H. Involvement and barriers to research amongst students of Khyber Medical College. J Postgrad Med Inst. 2013;27(3):297-302.

\section{Publish your work in this journal}

Advances in Medical Education and Practice is an international, peerreviewed, open access journal that aims to present and publish research on Medical Education covering medical, dental, nursing and allied health care professional education. The journal covers undergraduate education, postgraduate training and continuing medical education including emerging trends and innovative models linking education, research, and health care services. The manuscript management system is completely online and includes a very quick and fair peer-review system. Visit http://www.dovepress.com/testimonials.php to read real quotes from published authors.

Submit your manuscript here: http://www.dovepress.com/advances-in-medical-education-and-practice-journal 